\title{
ELECTRICAL RESISTIVITY TOMOGRAPHY (ERT) APPLIED IN THE DETECTION OF INORGANIC CONTAMINANTS IN SUSPENDED AQUIFER IN LEME CITY (BRAZIL)
}

\author{
Cesar Augusto Moreira ${ }^{1}$, Alan Carrara² , Lívia Portes Innocenti Helene ${ }^{3}$, Marco Antônio Fontoura Hansen ${ }^{4}$, \\ Walter Malagutti Filho ${ }^{1}$ and João Carlos Dourado ${ }^{1}$
}

\begin{abstract}
The assessment of contamination caused by improper disposal of solid waste involves integrated analysis of the physical environment, which shall range from the location of the pollutant source, flow paths and accumulation zones. The environmental diagnosis in complex aquifer systems shall clearly define the dimensions of the contaminated area by means of technical options that allow the adequate location of wells for quantification of contaminants. This work presents the results of Electrical Resistivity Tomography (ERT) to map the leachate originated from the decomposition of organic matter contained in clandestinely buried residues. Eight parallel lines were carried out in addition to one reference line, in an area defined from a satellite image history. The local geology consists of alternating centimetric layers of siltstones and argillites, with lenses of fine carbonate sandstones, deposited in a shallow marine environment under the influence of fluvial sedimentation. The analysis of the 2D inversion models based on the physicochemical characteristics of the leachate allowed the identification of individualized zones of electrical resistivity values lower than the natural minimum for the area, which shall reflect the origin, flow and accumulation of leachate. 3D models and multilevel electrical resistivity maps generated from the inversion models allowed for the detailing of low resistivity zones, which reveal leachate accumulation, disconnected and at various depths, located in suspended aquifers composed by levels of fine cemented sandstones.
\end{abstract}

Keywords: contamination, leachate, electrical resistivity, suspended aquifer, 3D modeling.

RESUMO. A avaliação de contaminações provocadas pela disposição indevida de resíduos sólidos envolve a análise integrada do meio físico, que deve abranger desde a localização da fonte poluidora, caminhos de fluxo e zonas de acumulação. 0 diagnóstico ambiental em sistemas aquíferos complexos deve claramente definir as dimensões da área contaminada por meio de opções técnicas que possibilitem a locação adequada de poços para quantificação de teores. Este trabalho apresenta os resultados de uso da tomografia elétrica no mapeamento de chorume proveniente da decomposição de matéria orgânica contida em resíduos enterrados de forma clandestina. Foram realizadas oito linhas paralelas além de uma linha de referência, em área definida a partir de um histórico de imagens de satélite. A geologia local é constituída por camadas centimétricas alternadas de siltitos e argilitos, com lentes de arenito fino cimentado por carbonatos depositados em ambiente marinho raso com influência de sedimentação fluvial. A análise dos modelos de inversão 2D baseada nas características físico-químicas do chorume, permitiu a identificação de zonas individualizadas de resistividade elétrica inferiores ao mínimo natural para a região, que devem refletir origem, fluxo e acúmulo de chorume. Modelos 3D e mapas multiníveis de resistividade elétrica gerados a partir dos modelos de inversão, possibilitaram 0 detalhamento das áreas de baixa resistividade, que revelam zonas de acúmulo de chorume independentes, desconexas e em diversas profundidades, situadas em aquíferos suspensos constituídos por níveis de arenito fino cimentado.

Palavras-chave: contaminação, chorume, resistividade elétrica, aquífero suspenso, modelamento 3D.

\footnotetext{
$\overline{1}$ Universidade Estadual Paulista (UNESP), Instituto de Geociências e Ciências Exatas (IGCE), Departamento de Geologia Aplicada, Rio Claro, São Paulo, Brazil - E-mails: moreirac@rc.unesp.br; malaguti@rc.unesp.br; jdourado@rc.unesp.br

2Universidade Estadual Paulista (UNESP), Instituto de Geociências e Ciências Exatas (IGCE), Graduação em Engenharia Ambiental, Rio Claro, São Paulo, Brazil - E-mail: alancarrara05@gmail.com

3 Universidade Estadual Paulista (UNESP), Instituto de Geociências e Ciências Exatas (IGCE), Rio Claro, São Paulo, Brazil - E-mail: liviapihelene@gmail.com

${ }^{4}$ Universidade Federal do Pampa (UNIPAMPA), Av. Pedro Anunciação, s/n, Vila Batista, 96570-000 Caçapava do Sul, RS, Brazil. Phone: +55(55) 3281-9000

- E-mail: mafhansen@gmail.com
} 


\section{INTRODUCTION}

The generation of domestic residues with high contents of organic matter is something intrinsic to the present way of life of populations of urban centers in countries under development such as Brazil. Tropical conditions with heat and rain distributed along the year enable the high quantities of fruit, leguminous and vegetables, set of foods that make up the basis of the eating habits of the country (Christensen et al., 1994).

The abundance of food available to the poorest layers of the population together with a wide net of logistics and distribution stimulated a culture of waste and discard of a substantial part of the volume of produced food. This kind of discarded organic matter represents over $50 \%$ of the total waste generated in households, with maximum exploitation of $3 \%$ of such material in composting (Cempre, 2013; ABRELPE, 2014).

The main form of final destination of solid residues in Brazil are the sanitary landfills (59\%), controlled landfills or dumps $(41 \%)$, where the collection and final destination are responsibility of the municipalities (IPEA, 2012; SNIS, 2013).

The dumps consist of a form of waste packaging characterized by their location in distant areas from the urban centers, the absence of any collection systems for gas or liquids produced by the decomposition of organic materials, absence of surface cover devices or soil sealing or control on the proliferation of insects, rodents or birds. On the other hand, the sanitary landfills are designed for final housing of waste with the smallest possible environmental impact, through installation of basal watersealing system, launch and conformation of the materials based on geotechnical criteria, collection of liquids and gases, atmospheric insulation by soil covering and conformation for structural stability (Tchobanoglous \& Kreith, 2002; Christensen, 2011; Reddy, 2011).

The planning and operation of sanitary landfills are dependent on a number of continuous licenses and supervision by State and federal environmental agencies, with costs managed by the city halls due to the absence of fees or taxes related to garbage. Like all civil works, the sanitary landfill has a lifetime for use based on the daily volume of waste stored and the usable area planned, which in Brazil is on average 20 years (IPEA, 2012; SNIS, 2013). This scenario, coupled with bureaucratic aspects that require some years between the initial planning and the full operation of a sanitary landfill requires long-term coordinated actions by the municipal public managers in waste management (ABRELPE, 2014).

The negligence of the city halls in waste management, in some cases, encourages the disposal of waste in inappropriate areas without any planning, as in public areas for relief conformation or fill of erosive features such as gullies. Such actions cause impacts to the environment, such as soil and groundwater contamination by products derived from the decomposition of organic matter such as leachate (Lehr et al., 2001; Sara, 2003; Twardowska et al., 2006).

The evaluation of contamination caused by improper disposal of solid waste involves the integrated analysis of the physical environment. The fundamental aspects necessary for the characterization of such areas suggest geological and hydrogeological studies (Hernández-Soriano, 2014; Yung-Tse et al., 2014).

The monitoring of contamination eventually present requires the detection, characterization, monitoring and prognoses about the flow of the contamination plumes generated on the ground and their possible effects to ecosystems. Chemical analyses on samples of soil and groundwater, characterized as direct forms of research, are tools traditionally employed in the study of contamination and necessary for the proposition of remediation techniques. However, this kind of analysis presents timely character and its evaluation is complex due to the discontinuities intrinsic to the geological environment (Rubin \& Hubbard, 2005; Knödel et al., 2007).

The application of geophysical methods in environmental studies, primarily in the characterization and monitoring of areas impacted by contaminants, is ascending in face of the demand for new techniques of environmental investigation, with emphasis on applications of Electrical and Electromagnetic methods in several case studies (Meju, 2000; Chambers et al., 2006; Abdullahi \& Osazuwa, 2010; Dena et al., 2012; Belmonte-Jiménez et al., 2012; Ramalho et al., 2012; Moreira et al., 2013, 2015, 2016; Ochoa-González et al., 2015; Arango-Galván et al., 2016; Gómez-Puentes et al., 2016).

The possibility of large-scale data acquisition at a relatively low cost allows a more accurate assessment of the environment, especially when integrated with direct results of investigation, although the geophysics is particularly relevant in the previous diagnosis of potentially contaminated areas, for the definition of targets for drilling, sampling and quantification of eventual pollutant levels (Knödel et al., 2007; Milsom \& Eriksen, 2011).

In this work, the DC Resistivity geophysical method was applied, through the technique of electrical resistivity tomography (ERT), with the purpose of assessing the existence of zones of flow or accumulation of leachate in hybrid aquifer (fractured and suspended), resulting from the degradation of organic matter contained in solid waste thrown erratically in public area in the municipality of Leme, southeastern Brazil. 


\section{LOCATION AND HISTORY}

The study area is located in the extreme north of Leme (SP), North Central region of the State of São Paulo, about $200 \mathrm{~km}$ far from the capital São Paulo (Fig. 1) a town with an estimated population of around 100,000 inhabitants and economy based on industry and agriculture.

The city currently generates $35 t /$ day of solid household waste, collected and discarded by city hall agents. A temporary landfill was opened in 1997 in Leme in face of requirements of the Environmental Agency of the State of São Paulo (CETESB), through a series of actions for conversion of dumps into sanitary landfills in all municipalities in the State. The CETESB authorized the operation of the area by a city's commitment in the construction of a definitive sanitary landfill, with all the technical specifications for the minimization of impacts to the environment.

This area was used until it reached full capacity in 2009, when the occupation of a nearby area was started until 2015, when there was the definitive ban on use of the area by CETESB due to the recurrent violation of several agreements of establishment of a technically suitable area for the installation of a sanitary landfill.

Despite the availability of provisional areas during this period, the improper disposal of household and construction waste was a common practice in vacant lots located in the boundaries of the municipality.

The study area was initially used for extraction of clay for a nearby brick factory, through withdrawal by backhoe and loading onto conventional trucks. The resulting cave became into use after 2009 for illegal disposal of household solid waste and construction materials such as bricks and tiles (Fig. 2).

In face of environmental preservation actions on the part of municipal public managers, the same was completely filled with waste in 2010. In an attempt to reduce the environmental impact of the direct exposure of the waste and reduce the spread of insects and rodents, the area was covered with soil and earth worked in 2011 (Fig. 2).

This procedure was part of a set of initiatives for elimination of illegal waste disposal practices in the municipality, with definition of fines and recovery of areas previously used in irregular ways. One of the initiatives taken to the final disposal of construction waste residues was the reuse and recycling of these materials in the own municipality.

In the scope of these actions, the area of studies in this work was assigned to private use and installation of a recycling company of civil construction waste, which started receiving materials for crushing and direct sale of aggregates for use in concrete, in addition to the manufacturing of bricks and cement floors (Fig. 2).

In 2016 the company operates in fully and search for the technical and environmental certification of their activities and produced materials, an initiative that justified the establishment of a set of technical procedures for environmental diagnosis of the area.

\section{GEOLOGICAL CONTEXT}

In the São Paulo State, the sedimentary and fractured aquifers dominate, besides aquicludes (Iritani \& Ezaki, 2009). The sedimentary aquifers are composed by materials deposited by the action of rivers, wind and sea, with circulation of fluids in pores between mineral grains and high water production capacity and are represented by the Guarani, Bauru, São Paulo, Taubaté and Coastal aquifers. The fractured aquifers are formed by igneous rocks and metamorphic rocks such as granites, gneisses, schists and metalimestones, characterized by compact rocks and absent of pores between minerals, with fluid circulation in cooling fractures or structural discontinuities derived from tectonic stresses. They are represented by the Serra Geral and Crystalline aquifers. The Passa Dois aquiclude encompasses siltites, argillites, marls and limestones rocks of the Irati and Corumbatai formations, typically waterproof or with very low local transmissivity (Fig. 3).

The geological context of the place of studies is represented by rocks of the Corumbatai Formation, belonging to the Group Passa Dois. This geological unit is characterized by argillites, shales and reddish and purple siltites with intercalation of carbonate banks and layers of very thin sandstones dated from the Permian/Triassic limit (Almeida et al., 1981; Rohn, 1994). In the upper portion of this unit, there is a succession of siltite layers, rhythmically alternating with thin laminates, with variable grain between argillaceous and thin sandy in horizons and layers.

The most common sedimentary features are plain-parallel stratification and crossed of low angle, corrugated marks and bedding of the flaser type (Ramos \& Formoso, 1975). Cracks from dryness, cross-lamination, wavy marks and stromatolite structures associated with oolitic limestones occur in a subordinate manner (Schneider et al., 1974). The mineral assembly is primarily composed of quartz, illite, montmorillonite and hematite, in addition to albite levels located and with genesis associated with diagenetic processes (Masson, 1997).

The sedimentary, faciological and fossiliferous structures indicate that the Corumbataí Formation is resulting from sedimentation in marine to epicontinental transitional environment (Schneider et al., 1974). The sedimentation would have occurred 


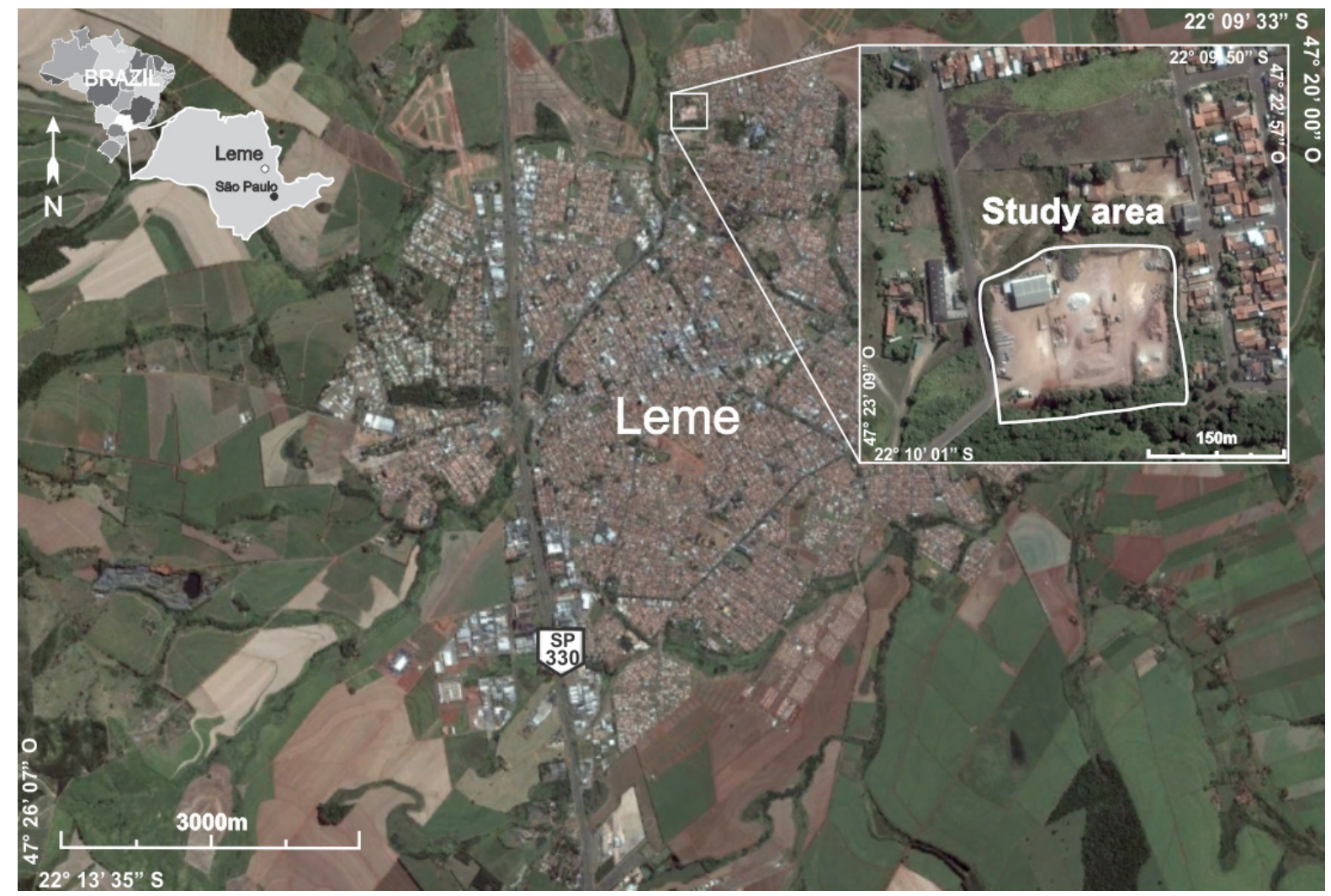

Figure 1 - Location of the study area (Adapted from Google Earth, 2016).

initially in relatively deep waters in the high seas, preferably in the area of transition between the high seas and the beach line. Marine regression events were alternated by frequent sea level fluctuations that resulted in short regressive-transgressive cycles, with recurrence of high sea deposits, transition zone and tidal plains, primarily in sub-aqueous environment.

The seasonality between periods of rainy and dry climate is the main hypothesis that justifies this alternation between silt and clay layers. During periods of rainy weather there should occur a great income of continental sediments in the intracratonic marine environment, with turbulence and sufficient energy for the scattering of silt particles. The periods of dry climate should result in calm marine waters and decanting of particles of clay in suspension.

As it is composed of predominantly fine sediments, its ability to supply water is quite low and with insufficient productivity for the supply of large communities. In this way, it is regionally called an aquiclude, although ranked locally as aquitard, due to presenting fractures with certain water productivity (DAEE, 1982; Iritani \& Ezaki, 2009).

In the area of studies there is a rhythmic succession of siltites and argillites of centimetric thickness and extensive lateral con- tinuity. Clay levels feature intense vertical fracturing, relatively limited at silt levels, with flow in fractured system. Locally thin sandstone lenses occur impregnated by carbonatic cement which makes this rock extremely massive and compact, with limited lateral continuity between 8 to $15 \mathrm{~m}$ and forming suspended multilevel aquifers (Fig. 3).

The alteration soil of the Corumbataí Formation presents high clay content and very low transmissivity, with average hydraulic conductivity of $6.5 \times 10^{-7} \mathrm{~cm} / \mathrm{s}$ (Cottas, 1984).

\section{MATERIALS AND METHODS}

The DC Resistivity method is based on generating an electric field by injecting an electric current $(I)$ through metal rods, called the transmitter circuit. The electric potential $(\Delta V)$ produced by this field is captured by a receiver circuit, which can also be represented by metallic rods or non-polarizable electrodes. Applying Ohm's Law the electrode spacing, represented by $K$ factor, enables measuring the apparent resistivity parameter $(\rho a)$ for various depth levels (Milsom \& Eriksen, 2011).

The electrical resistivity is an intrinsic property in soil and rock, defined by current density over gradient of electrical poten- 

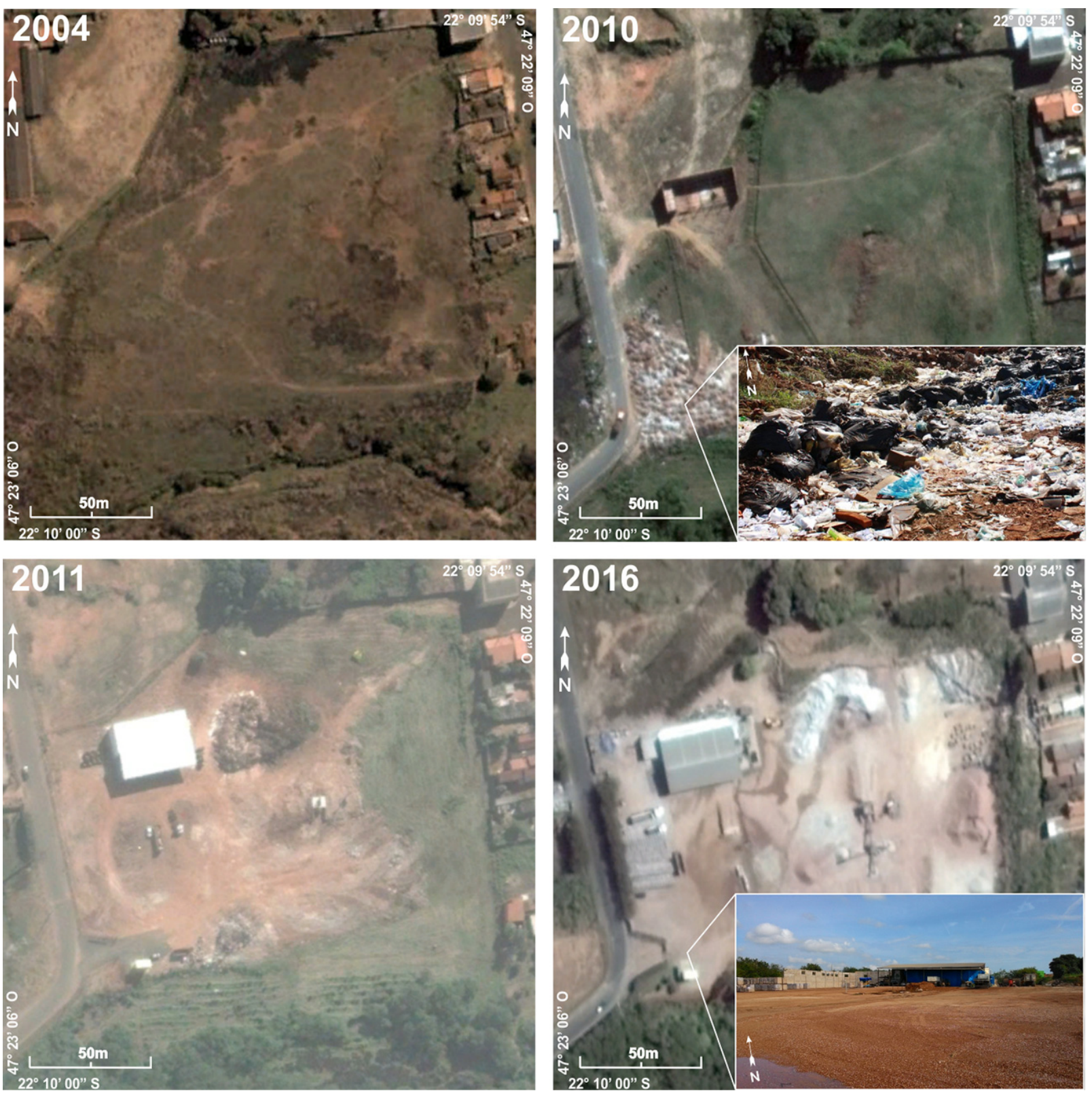

Figure 2 - History of use and occupation of the study area: public area without use in 2004, release of solid waste in 2010, ground coverage and earthwork of the residues in 2011, cession of the area for the installation of civil construction residues crushing industry and situation in 2016.

tial. Resistivity changes an earth material, either vertically or laterally, produce changes in the relations between the applied current and the potential distribution as measured at the surface, and reflect changes in composition, extent, and physical properties of the subsurface materials. Properties that affect resistivity of a soil or rock include porosity, water content, composition (clay mineral and metal content), salinity of pore water, and grain size distribution (Milsom \& Eriksen, 2011).
The works consisted of 9 lines of electric resistivity tomography with $80 \mathrm{~m}$ in length each, for electrical resistivity readings at various depths. It was adopted the Schlumberger array, with spacing between electrodes of $2 \mathrm{~m}$ and $10 \mathrm{~m}$ and $13 \mathrm{~m}$ of spacing between lines (Fig. 4).

The selection of this research method is based on the contrast of electrical properties between natural soil and a potential soil with leachate. The natural soil presents high resistivity 


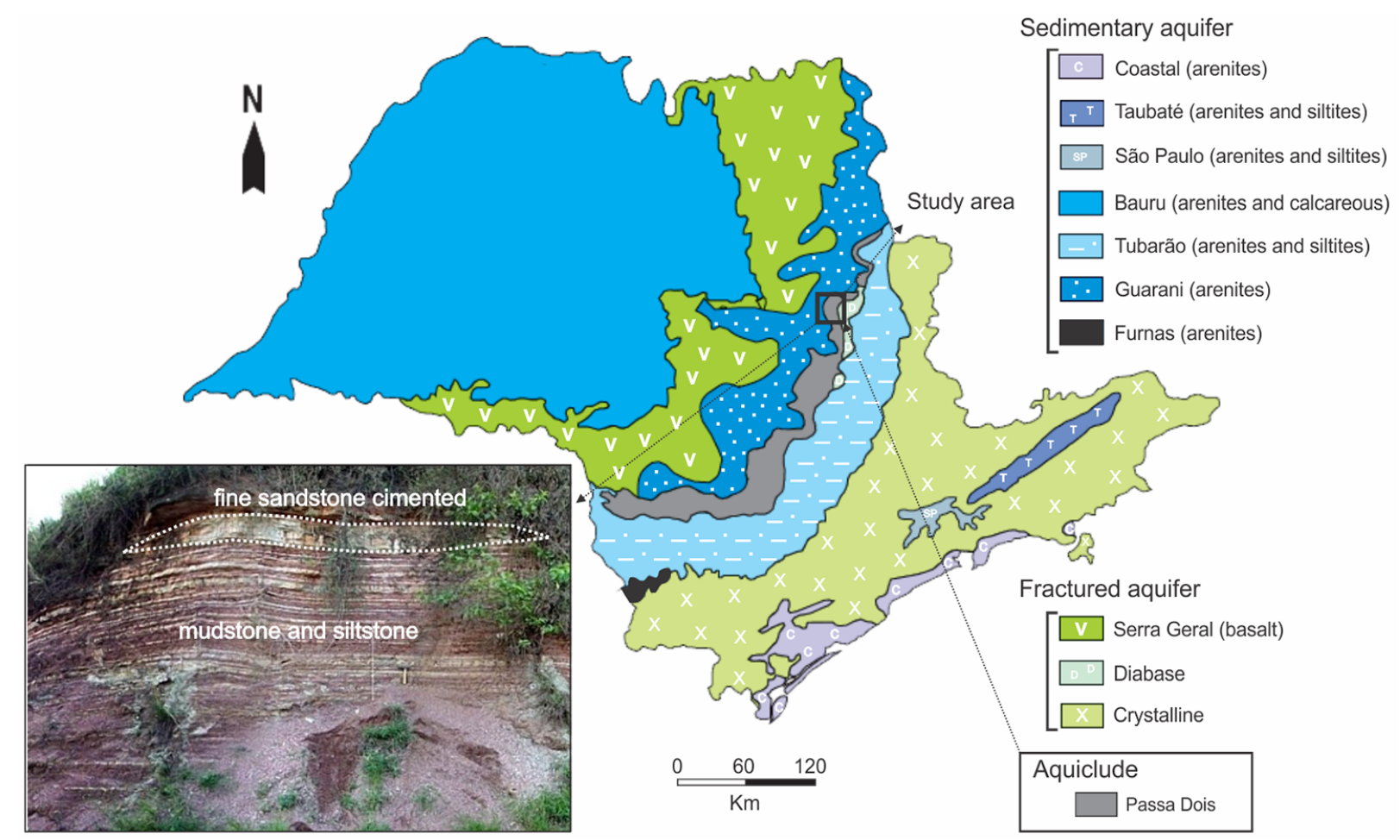

Figure 3 - Main aquifers in the State of São Paulo, highlighting the Passa Dois aquiclude, outcropping in the study area (Adapted from Iritani \& Ezaki, 2009).

values, due to its quartz and other minerals. The definition of the natural pattern of local resistivity was done from a reference line on the access road to the area, positioned upstream of the groundwater flow.

The geophysical equipment used was the Terrameter LS resistivity meter, manufactured by ABEM Instrument (Sweden), which consists in a single module of transmission and reception of signals, automated from previous programming, with $250 \mathrm{~W}$, resolution of $1 \mu \mathrm{V}$ and maximum current of $2,5 \mathrm{~A}$. It enables the performance of spontaneous potential essays (SP), electro resistivity (ER) and induced polarization (IP) by means of periodic cycles of transmission and reception of signals, automated calculation of the contact resistivity and standard deviation from the measurement set (ABEM, 2012). The equipment was calibrated for injection in the soil of $100 \mathrm{~mA}$ current and 1s of transmission time.

The electrical tomography data were tabulated in a spreadsheet editor, along with geographic coordinates and altitude in each point, subsequently processed in the program RES2DINV (Geotomo-Malaysia). The sections are presented in terms of distance $\times$ depth, with logarithmic graphic scale and intervals of interpolation of color values.
The method of inversion by smoothing uses the mathematical method of least squares, and through it, the software recognizes the terrestrial subsurface as rectangular blocks that have constant values for the investigated parameter (Loke, 2003). This optimization aims to reduce the difference between the apparent resistivity values, calculated and measured in the field, by adjusting the resistivity of the block model, which difference is expressed by the RMS error (Root Mean Squared) (Loke \& Barker, 1996).

The 2D inversion considered the basic procedures recommended in the program manual, without using algorithms or specific filtrations. The individual analysis of $2 \mathrm{D}$ inversion models allowed the definition of a range of logarithmic and representative values of the set, which was adopted as a single scale to contribute to a comparative analysis between 2D and 3D modeling.

The numeric product of a two-dimensional inversion of data of each section was gathered in a single spreadsheet, which unites the position of the readings along the lines (variable " $x$ "), spacing among lines (variable " $y$ "), depth modeled by the inversion (variable "z") and the value of electrical resistivity (variable "R"). This spreadsheet was used for the generation of $3 \mathrm{D}$ viewing models, in a routine of basic steps adopted in mineral research. 


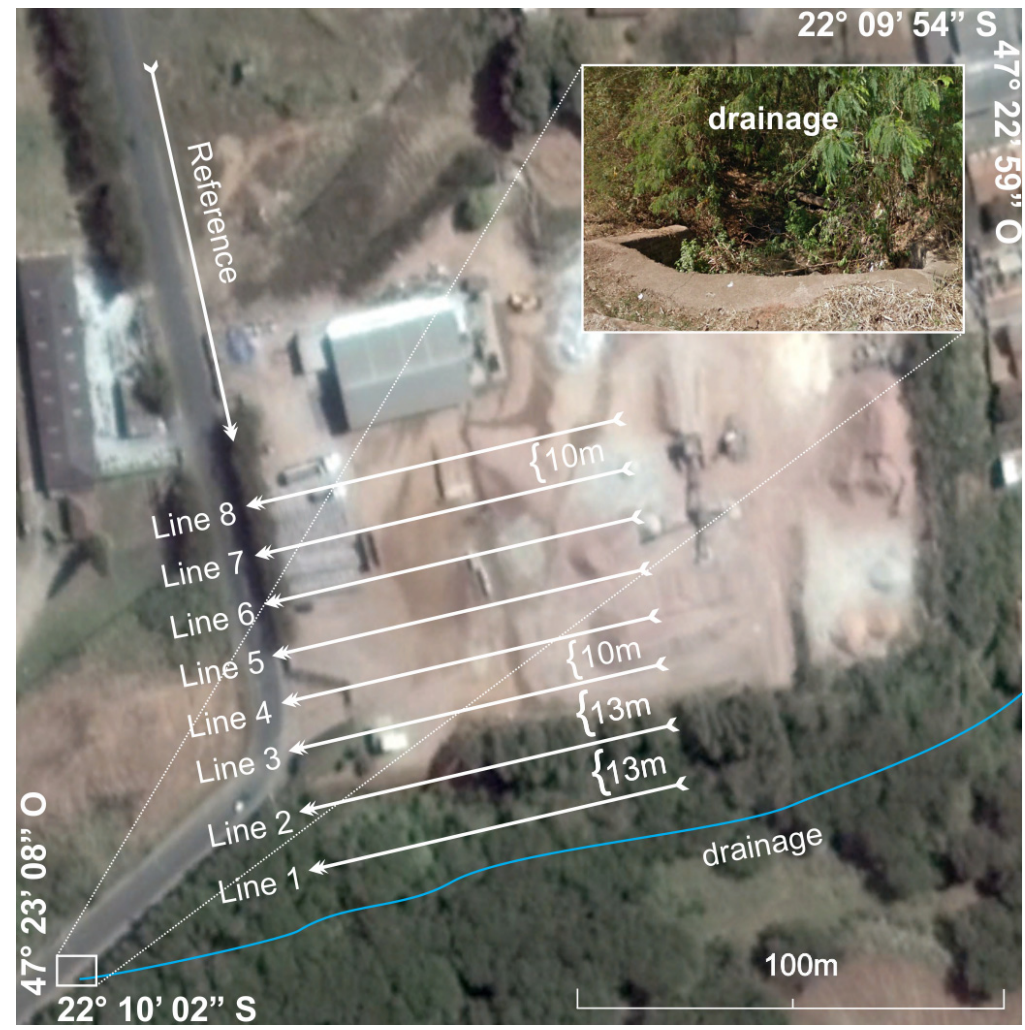

Figure 4 - Electrical resistivity tomography lines in the study area, highlighting the drainage located in the southern.

In this case, the sampling plan is frequently defined from statistic, structural criteria, spatial placement of a mineral accumulation, among others (Moon et al., 2006).

Thus, the 2D model sections were then exported from RES2DINV and re-imported into the Oasis Montaj Platform (Geosoft), in order to create a 3D visualization model for the chargeability, without adjustment of topographic data. 3D visualization models generated from geophysical data are of great help in the understanding of complex geological structures in mineral exploration and environmental studies (Aizebeokhai et al., 2011; Houlding, 2012; Côrtez et al., 2016; Moreira et al., 2016; Vieira et al., 2016).

\section{RESULTS AND DISCUSSIONS}

The analysis and interpretation of geophysical data must necessarily be based on the temporal behavior of waste buried in the area of studies. Inert waste such as plastics, paper or rubber presents no risk of eminent or short term contamination. However, the fraction of organic wastes contained in these materials goes through physical and chemical changes under anaerobic conditions, i.e. after the soil coverage and isolation from any atmospheric contact (Themelis \& Ulloa, 2007; Reddy, 2011).
This process occurs in three main phases (Christensen et al., 1994; Vesilind et al., 2002; Tchobanoglous \& Kreith, 2002). The first stage occurs in oxidizing conditions, with degradation of the organic matter by infiltration of rain water and generation of carbon dioxide, water, acids and release of mineral salts. The fall in the rate of available oxygen provides the installation of reducing conditions that predominate in the later stages of degradation. The action of fermentative bacteria results from the hydrolysis of complex organic matter conversion in soluble molecules, subsequently converted into simple organic acids, ethanol, carbon dioxide and hydrogen. In the most advanced stage predominates the generation of methane, organic acids and release of mineral salts dissolved in water.

The main products of degradation of organic matter are gaseous and liquid compounds. The biogas consists of methane, carbon dioxide, sulphidric gas and water vapor, which tend to migrate to shallower positions and escape to the atmosphere. The leachate represents the liquid fraction, consisting of organic acids (humic, fulvic, fatty), inorganic elements ( $\mathrm{Ca}, \mathrm{Mg}, \mathrm{Na}, \mathrm{K}, \mathrm{Fe}, \mathrm{Mn}$, $\mathrm{Cl}, \mathrm{NH}_{4}^{+}, \mathrm{SO}_{4}^{2+}, \mathrm{HCO}_{3}^{-}$), metals ( $\mathrm{Cd}, \mathrm{Cr}, \mathrm{Cu}, \mathrm{Pb}, \mathrm{Ni}$ and $\mathrm{Zn}$ ) besides organic compounds derived from petroleum (Farquhar, 1989; Mara, 2003). 
The saline solution is fully miscible in water and initially reaches the aquifer by gravity flow, subsequently conditioned to the gradient of underground flow. In this sense, the possible presence of leachate in the aquifer can be recognized due to increased electrical conductivity (Meju, 2000; Knödel et al., 2007).

In this sense, zones of flow or accumulation of leachate in the soil and groundwater should result in the fall of the resistivity values in relation to the natural pattern for the area. Therefore, data analysis and data interpretation is based on the comparison between natural resistivity values obtained upstream of the area investigated, and data obtained in the area suspected of contamination.

The study area began receiving waste in 2010 and after 6 years of coverage and isolation from atmospheric contact by an extremely clay soil, possibly predominate highly reducing conditions, and the duration of anaerobic biodegradation.

The proximity of a drain on the southern edge of the area implies in shallow groundwater level and conditions of partial saturation of waste. In this sense, the local topographic boundary clearly indicates a water flow from the aquifer free to the South, with vertical migration in unsaturated zone of contaminants eventually generated in the waste, dissolution in the aquifer and flow to the South. This hypothesis justified the planning of the electrical resistivity tomography lines, programmed in order to intercept the flow of contaminants in the area of studies to the drainage.

The field data were processed and generated inversion models in terms of electrical resistivity, consisting of sections with distance and depth, with values between 1 0hm.m (cool colors) and 300 0hm.m (warm colors).

The electrical resistivity inversion models resulted in sections with investigation depth of $15 \mathrm{~m}$, grouped into sets that enable comparisons with the reference section, made upstream the groundwater flow. This section allowed defining the minimum resistivity standard natural to the free aquifer existent in the area, value taken in comparisons with the other sections. The minimum value described in the reference section was 11.5 0hm.m.

A preliminary analysis of the results allows the recognition of zones with electrical resistivity values below the minimum recognized in the area (11.5 0hm.m), up to the minimum of $1 \mathrm{Ohm} . \mathrm{m}$. The saline character of the leachate is the main responsible for this pattern of resistivity, i.e., anomalous values to the natural standard to materials in the area. These areas were highlighted in the sections for higher clarity, along with the main sources of generation of leachate and main lines of vertical flow (Fig. 4).
The horizontal accumulation zones shall match the placement of saline contaminants at the base of the free aquifer, which for the sections obtained near the drainage (lines 1 and 2), correspond to a maximum $-7 \mathrm{~m}$ of deep

In the sections of lines 3 to 7 vertical anomalous zones are recognized connected with shallow sources and that reach the base of the sections, indicating flow in vertical fractures system, with clear continuity under $-15 \mathrm{~m}$ of maximum depth of research in this study. These areas shall represent area of slow flow and accumulation of leachate in fractures (Fig. 4).

In order to demonstrate the lateral continuity of the anomalous resistivity zones between rows, the inversion models were interpolated in 3D visualization models and later allowed the generation of electrical resistivity maps for the depths of $-1 \mathrm{~m},-5 \mathrm{~m}$, $-9 \mathrm{~m}$ and $-15 \mathrm{~m}$. Integrated to the models, 3D isosurface models were also generated with the resistivity value of $5 \Omega . \mathrm{m}$ (Fig. 5).

In $-1 \mathrm{~m}$ of depth, high resistivity values predominate, only with exception of one elongated track with lower value to the natural minimum for the area $(11.5 \Omega . \mathrm{m})$. In the map for $-5 \mathrm{~m}$ depth low resistivity values predominate, with emphasis on two areas with values below $11 \Omega . \mathrm{m}$. This trend is recurring on the maps for the depths $-9 \mathrm{~m}$ and $-15 \mathrm{~m}$, where areas of resistivity values below $11.5 \Omega$.m also occur.

Analysis of isosurface 3D models indicates that the bodies of low resistivity are unrelated and are seated at different depths. The shallower body features the base situated $-2 \mathrm{~m}$ deep, while the bodies outcropping at $-5 \mathrm{~m}$ and $-9 \mathrm{~m}$ feature the base located $-10 \mathrm{~m}$ deep. The maximum depth of investigation was limited to $-15 \mathrm{~m}$, but the zones of low resistivity initiated at this level should continue in greater depths (Fig. 5).

The analysis of geophysical data in face of the local hydrogeological context allows affirming that the leachate generated by the degradation of organic matter buried in the area, presents vertical migration in fractured aquifer system. However, the apparent accumulation of leachate in pockets or contamination plumes at $-2 m$ and $-10 m$ of depth shall be indicative of the existence of thin sandstone lenses cemented and waterproof. The existence of individual contamination plumes is another indicative of lenses of small lateral continuity.

In exhibitions of surface outcrop it is possible to recognize that such lenses have between $5 \mathrm{~m}$ and $10 \mathrm{~m}$ in length. Corumbataí Formation is a geological unit formed by the accumulation of fine sediment in shallow and coastal marine environment. In the extent where there was the gradual installation of desert climatic conditions, occurs the increasing regression of the shore 


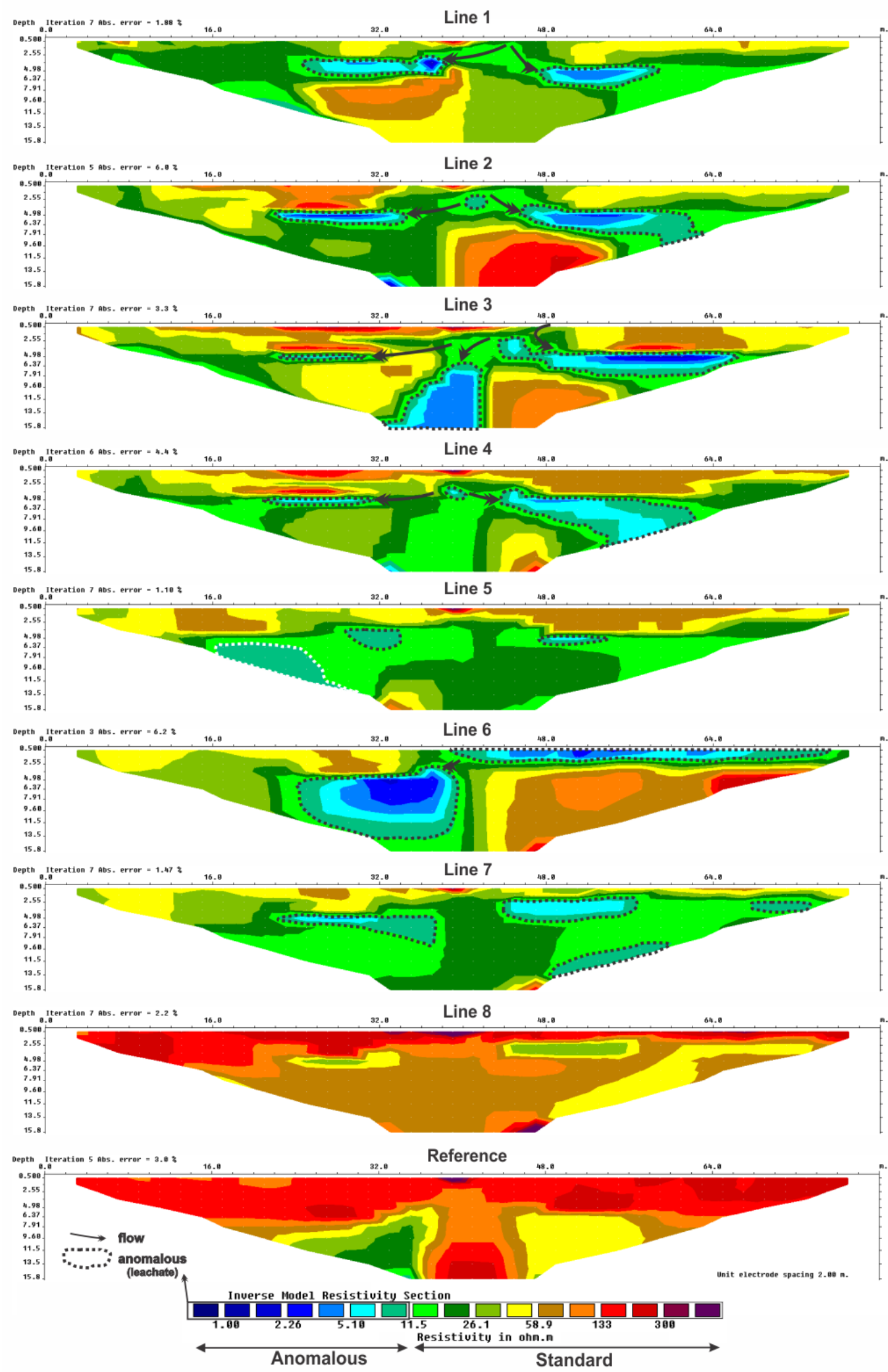

Figure $\mathbf{5}$ - Models of resistivity inversion of lines 1 to 8 , highlighting anomalous areas in comparison to the standard reference. 

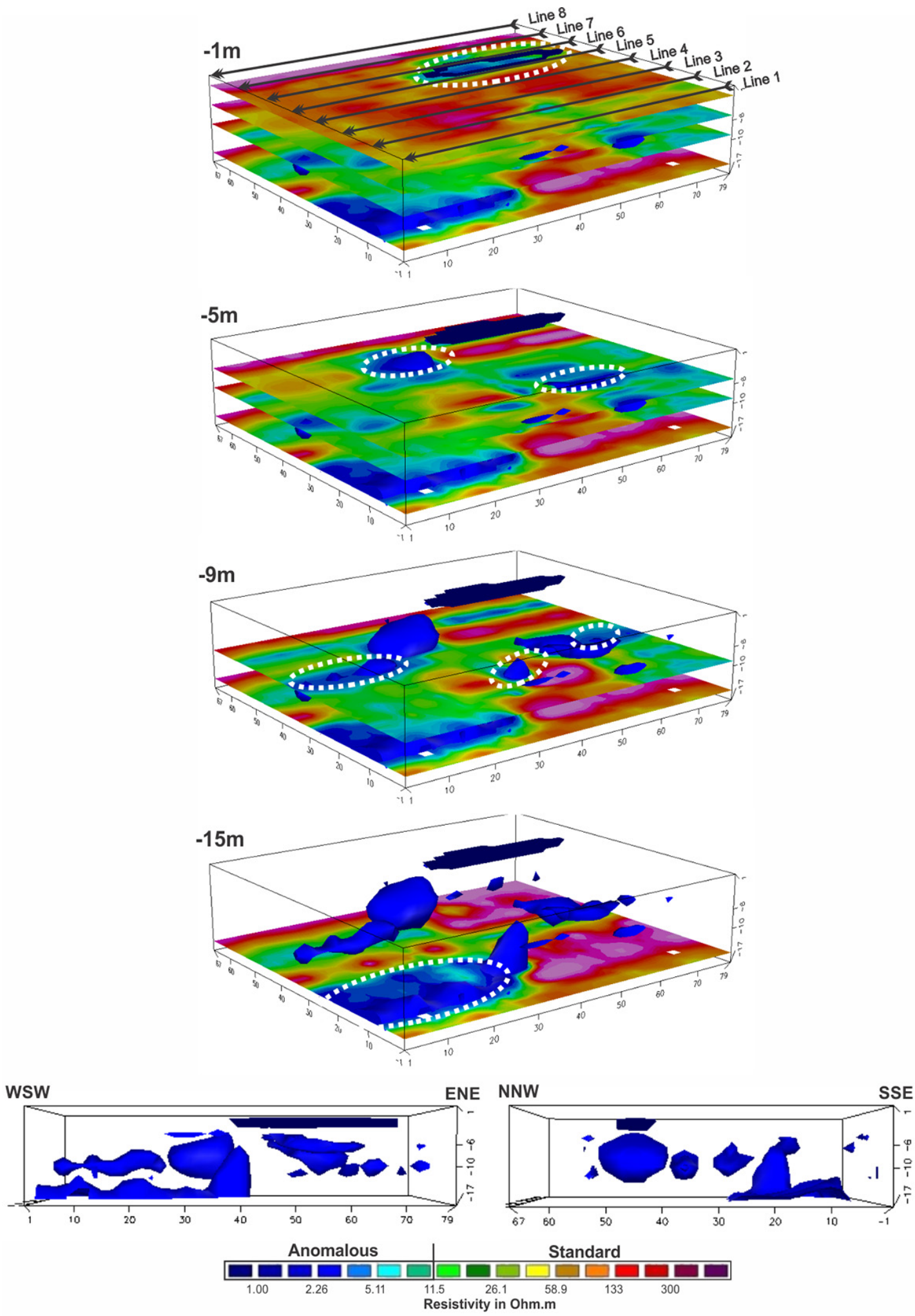

Figure 6 - Electrical resistivity maps for various depths (indicated in the top left corner), position of the electrical tomography lines and highlight of anomalous zones (contaminated zones). 
line towards central portions of the marine environment. The advancement of meander drainage channels in the plain of tide allowed for the random distribution of thin sandstone lenses in dry beds, later submitted to carbonate cementation during diagenesis. The gradual evaporation of marine waters is succeeded by a fluvial deltaic depositional environment, which originated a geological unit named Pirambóia Formation.

The genetic context and descriptive indications in rock outcrops, combined with analysis of 3D visualization models and associations with areas of accumulation of leachate from the decomposition of organic matter contained in the buried waste, allow concluding the existence of fractured and suspended aquifer. The vertical fractures in the alternating layers of mudstone and siltstone allow the gravitational flow of fluids of superficial origin, while the fine sandstone cemented layers act as impermeable layers and with depositional architecture of lenticular shape, responsible for the support of individually suspended aquifers.

\section{CONCLUSIONS}

The absence of minimum technical criteria in the final disposal of household solid waste often causes damage to the environment and to nearby populations. The grounding and earthwork of landfills for urban expansion is a recurring alternative in many Brazilian municipalities, but that simply hides problems with harmful consequences. By-products of the degradation of organic matter accumulated in the buried residues and in the geological environment significantly increase the risk of explosion and contamination of groundwater.

The availability of a history of satellite imagery for the area of studies provided an analysis of use and occupation of the area. Subsequent earthworks have resulted in the current shaping of the local relief and in the complete concealment of evidence of buried waste. In this sense, the history of satellite images is an efficient resource and of low cost in identifying priority areas for detailed studies.

Geophysical surveys planned from this history of use and occupation, geological criteria and behavior of contaminants in the geological environment, allowed a glimpse of areas of flow and accumulation of contaminants derived from the degradation of organic matter contained in the buried waste. Analysis of physicochemical properties of leachate and the review of works on the application of geophysics in the study of contaminated areas, made it possible to define the most appropriate geophysical method in terms of sensitivity in the definition of contrasts between the natural environment and potentially contaminated areas.
The acquisition of electrical resistivity tomography data in regular mesh, $2 \mathrm{D}$ inversion processing and subsequent interpolation in 3D visualization models enabled the generation of highresolution products. The use of geochemical data interpolation techniques in 3D modeling of mineral deposits adapted to geophysical data modeling of $2 \mathrm{D}$ inversion, made possible the elaboration of multilevel maps of electrical resistivity and adjustment of $3 \mathrm{D}$ isosurface models with anomalous value to the natural pattern of the area.

The local topography is characterized by a slight slope in the SW direction, with drainage in the lower portion of the area, a condition that justified the orientation of the electrical tomography lines. This topographic gradient on a sedimentary substrate suggests at first a flow direction of contaminants from the highest source areas for local drainage. However, evidence indicated by 3D geophysical modeling points to multilevel and restricted areas of flow in some points, contained in highly clayey geological materials. It is possible to affirm the predominance of flow in a fractured system, with a tendency of vertical movement limited to the continuity and connectivity of the fractures.

The presence of lenses of massive cemented sandstone between layers of fractured argillite and silt characterizes the existence of a hybrid aquifer system, predominantly fractured but with suspended aquifer in localized levels. This setting justifies the gravitational flow of leachate through fractures and the accumulation of discontinuous multi-level horizons. The definition of this type of system only by means of monitoring wells would require a detailed and costly network.

The alternative of geophysical detailing by electrical tomography enabled the definition of specific targets for installation of sampling points and quantification of levels, in addition to serving the planning of optimized remediation system with high probability for the recovery of contaminated areas in the short term.

\section{REFERENCES}

ABEM. 2012. Terrameter $L S$ - Instruction Manual. ABEM Instrument AB, Sundbyberg, $122 \mathrm{pp}$.

ABDULLAHI NK \& OSAZUMA IB. 2010. Geophysical imaging of municipal solid waste contaminant pathways. Environmental Earth Science, 62: 1173-1181.

ABRELPE - ASSOCIAÇÃO BRASILEIRA DE EMPRESAS DE LIMPEZA PÚBLICA E RESÍDUOS ESPECIAIS. 2014. Panorama dos resíduos sólidos no Brasil. Abrelpe, São Paulo, Brazil, 120 pp.

AIZEBEOKHAI AP, OLAYINKA AI, SINGH VS \& UHUEGBU CC. 2011. Effectiveness of 3D geoelectrical resistivity imaging using parallel 2D profiles. International Journal of the Physical Sciences, 6: 5623-5647. 
ALMEIDA FF, HASUI U, PONÇANO WL, DANTAS ASL, CARNEIRO CDR, MELO MS \& BISTRICHI CA. 1981. Mapa Geológico do Estado de São Paulo. Instituto de Pesquisas Tecnológicas, São Paulo, Brazil.

ARANGO-GALVÁNC, FLORES-MÁRQUEZEL, HERNÁNDEZ-ESPRIÚJA, ARIAS-PAZA \& SAGAHÓN-LÓPEZEJ. 2016. Shallow geoelectrical characterization of a small portion of the Basin of Mexico aquifer: Towards a better resource management. Geofísica Internacional, 55: 215-225.

BELMONTE-JIMÉNEZ S, JIMENEZ-CASTAÑEDA ME, PÉREZ-FLORES MA, CAMPOS-ENRÍQUEZ J, REYES-LÓPEZ JA \& SALAZAR-PEÑA L. 2012. Characterization of a leachate contaminated site integrating geophysical and hydrogeological information. Geofísica Internacional, 51 : 309-321.

CEMPRE - COMPROMISSOEMPRESARIAL PARA RECICLAGEM. 2013. Review - um panorama dos resíduos sólidos no Brasil. Cempre, São Paulo, Brazil, 24 pp.

CHAMBERS JE, KURAS 0, MELDRUM PI, OGILVY RD \& HOLLANDS J. 2006. Electrical resistivity tomography applied to geologic, hydrogeologic, and engineering investigations at a former waste-disposal site. Geophysics, 71: 231-239

CHRISTENSEN TH. 2011. Solid Waste Technology \& Management. John Wiley \& Sons, Chichester, 1026 pp.

CHRISTENSEN TH, KJELDSEN P, ALBRECHTSEN HJ, HERON G, NIELSEN PH \& BJERG PL. 1994. Attenuation of landfill leachate pollutants in aquifers. Critical Review in Environmental Science and Technology, 24: 119-202.

CÔRTES ARP, MOREIRA CA, VELOSO DIK, VIEIRA LB \& BERGONZONI FA. 2016. Geoelectrical prospecting for a copper-sulfide mineralization in the Camaquã sedimentary basin, Southern Brazil. Geofísica Internacional, 55: 107-117.

COTTAS LR. 1984. Estudos geológicos-geotécnicos aplicados ao planejamento urbano de Rio Claro - SP. Doctorate Thesis in Geology. Instituto de Geociências, Universidade de São Paulo, São Paulo, Brazil, 177 pp.

DAEE. 1982. Carta Hidrogeológica do Estado de São Paulo (1:500.000). Departamento de Água e Energia Elétrica do estado de São Paulo, São Paulo, Brazil.

DENA OS, GRISELDA OBESO C, DOSER D, LEYVA JE, RASCON E, GÓMEZ F \& DOMÍNGUEZ MA. 2012. Using subsurface geophysical methods in flood control: A resistivity survey to define underground storage capacity of a sand body in Ciudad Juárez, Mexico. Geofísica Internacional, 51: 225-249.

FARQUHAR GJ. 1989. Leachate: production and characterization. Canadian Journal of Civil Engineering, 16: 317-325.

GÓMEZ-PUENTES FJ, PÉREZ-FLORES MA, REYES-LÓPEZ JA, LOPEZ DL, HERRERA-BARRIENTOS F, GARCÍA-CUETO RO, ROMERO-HER-
NÁNDEZ S, SÓLIS-DOMÍNGUEZ FA \& GARRIDO MML. 2016. Geochemical modeling and low-frequency geoelectrical methods to evaluate the impact of an open dump in arid and deltaic environments. Environmental Earth Science, 75: 1062.

HERNÁNDEZ-SORIANO MC. 2014. Environmental risk assessment of soil contamination. InTech, New York, 920 pp.

HOULDING S. 2012. 3D Geoscience Modeling: Computer Techniques for Geological Characterization. Springer, Heidelberg, 297 pp.

IPEA - Instituto de Pesquisas Econômicas Aplicadas. 2012. Diagnóstico dos Resíduos Sólidos Urbanos. Secretaria de Assuntos Estratégicos, Brasília, Brazil, 82 pp.

IRITANI MA \& EZAKI S. 2009. As águas subterrâneas do Estado de São Paulo. Secretaria de Estado do Meio Ambiente, São Paulo, Brazil, 104 pp.

KNÖDEL K, LANGE G \& VOIGT HJ. 2007. Environmental Geology Handbook of Field Methods and Case Studies. Springer-Verlag, Berlin, $1193 \mathrm{pp}$.

LEHR J, HYMAN M, GASS TS \& SERVERS WJ. 2001. Handbook of complex environmental remediation problems. McGraw-Hill Handbooks, New York, 640 pp.

LOKE MH. 2003. RES2DINV-Rapid 2D Resistivity and IP Inversion using the Least-Squares Method. Geotomo Software Manual, Malaysia.

LOKE MH \& BARKER RD. 1996. Rapid least-squares inversion of apparent resistivity pseudosections by a quasi-Newton method. Geophysical Prospecting, 44: 131-152.

MARA DD. 2003. Domestic wastewater treatment in developing countries. Earthscan, London, $289 \mathrm{pp}$.

MASSON MR. 1997. Rochas da Formação Corumbataí como matériaprima para a indústria cerâmica: sua influência na qualidade dos produtos. Master Dissertation, Geologia Regional, Instituto de Geociências e Ciências Exatas, Universidade Estadual Paulista, São Paulo, Brazil, $143 \mathrm{pp}$.

MEJU MA. 2000. Geoelectrical investigation of old/abandoned, covered landfill sites in urban areas: model development with a genetic diagnosis approach. Journal of Applied Geophysics, 44: 115-150.

MILSOM JJ \& ERIKSEN A. 2011. Field Geophysics. John Wiley \& Sons, Chichester, $297 \mathrm{pp}$.

MOON CJ, WHATELEY MEG \& EVANS AM. 2006. Introduction to Mineral Exploration. Blackwell Publishing, Oxford, 499 pp.

MOREIRA CA, GODOY LH, SARDINHA DS, CONCEIÇÃO FT \& DEL ROVERI C. 2013. Caracterização geofísica em aterro de resíduos sólidos para avaliação de condicionantes de instabilidade geotécnica. Geologia USP Série Científica, 13: 2-34.

MOREIRA CA, MUNHOZ T, CAVALLARI F \& HELENE LPI. 2015. Electrical resisitivity to detect zones of biogas accumulation in a landfill. Geofísica Internacional, 54: 353-362. 
MOREIRA CA, LAPOLA MM \& CARRARAA. 2016. Comparativeanalyzes among electrical resistivity tomography arrays in the characterization of flow structure in free aquifer. Geofísica Internacional, 552: 119-129.

OCHOA-GONZÁLEZ GH, CARREÓN-FREYRE D, CERCA M \& LÓPEZMARTÍNEZ M. 2015. Assessment of groundwater flow in volcanic faulted areas. A study case in Queretaro, Mexico. Geofísica Internacional, 54(3): 199-220.

RAMALHO EC, DILL AC \& ROCHA R. 2012. Assessment of the leachate movement in a sealed landfill using geophysical methods. Environmental Earth Sciences, 68: 343-354.

RAMOS NA \& FORMOSO MLL. 1975. Argilominerais das Rochas Sedimentares da Bacia do Paraná. Rio de Janeiro, Brazil: Petrobras, 9: 83.

REDDY PJ. 2011. Municipal Solid Waste Management: Processing, Energy Recovery, Global Examples. CRC Press, Boca Raton, 470 pp.

ROHN R. 1994. Evolução ambiental da Bacia do Paraná durante o Neopermiano no leste de Santa Catarina e do Paraná. Doctorate Thesis in Geology, Instituto de Geociências, Universidade de São Paulo, São Paulo, Brazil, 480 pp.

RUBIN Y \& HUBBARD SS. 2005. Hydrogeophysics. Springer, Dordrecht, $527 \mathrm{pp}$.

SARA M. 2003. Site assessment and remediation handbook. 2nd ed., Lewis Publishers, Florida, 1161 pp.

Recebido em 18 maio, 2017 / Aceito em 7 março, 2018

Received on May 18, 2017 / Accepted on March 7, 2018
SCHNEIDER RL, MÜHLMANN H, TOMMASIE, MEDEIROS RA, DAEMON RF \& NOGUEIRA AA. 1974. Revisão estratigráfica da Bacia do Paraná. In: Congresso Brasileiro de Geologia, 28., 1974, Porto Alegre. Anais... São Paulo, Brazil. Sociedade Brasileira de Geologia, 1: 41-65.

SNIS - SISTEMA NACIONAL DE INFORMAÇÕES SOBRE SANEAMENTO. 2013. Diagnóstico dos Serviços de Água e Esgotos. Ministério das Cidades, Brasília, Brazil, 191 pp.

TCHOBANOGLOUS G \& KREITH F. 2002. Handbook of solid waste management. McGraw-Hill, New York, 950 pp.

THEMELIS NJ \& ULLOA PA. 2007. Methane generation in landfills. Renewable Energy, 32: 1243-1257.

TWARDOWSKA I, ALLEN HE, HÄGGBLOM MH \& STEFANIAK S. 2006. Soil and water pollution: monitoring, protection and remediation. Nato Science Series, Springer, Krakom, 662 pp.

VESILIND PA, WORRELL W \& REINHART D. 2002. Solid waste engineering. Brooks/Cole, Pacific Grove, 428 pp.

VIEIRA LB, MOREIRA CA, CÔRTES ARP \& LUVIZOTTO GL. 2016. Geophysical modeling of the manganese deposit for Induced Polarization method in Itapira (Brazil). Geofísica Internacional, 55: 107-117.

YUNG-TSE H, WANG LK \& SHAMMAS NK. 2014. Handbook of environment and waste management: land and groundwater pollution control. World Scientific, Toh Tuck Link, 1116 pp. 